\title{
The composition and evolution of an Oligocene regolith on top of the Sesia-Lanzo Zone (Western Alps)
}

\author{
Notburga Kapferer • Ivan Mercolli • \\ Alfons Berger
}

Received: 13 January 2010/Accepted: 23 December 2010/Published online: 12 February 2011

(C) Springer-Verlag 2011

\begin{abstract}
An Oligocene paleosurface (regolith) lies on top of the high-pressure metamorphic rocks of the SesiaLanzo Zone near Biella, NW Italy. Only the saprock, the lowermost part in a regolith profile, is preserved. No evidence for any paleosoil can be observed. Field observations indicate that the regolith developed through in situ mechanical fracturing of the rocks of the Sesia-Lanzo Zone in a continental environment. Density estimations of the regolith and the underlying rocks of the Sesia-Lanzo Zone confirm the field observations and imply that a relatively small amount of alteration minerals was formed. The main detected alteration phases are chlorite, various carbonates, quartz, clay minerals, Fe-oxides, and Fe-hydroxides. Chlorite differing in chemistry and crystallographic ordering demonstrates different stages of alteration. Oxygen and carbon isotopic composition of carbonates suggests temperatures higher than surface conditions. Illite and chlorite thermometry indicates temperatures related to the anchizone $\left(\sim 250-300^{\circ} \mathrm{C}\right)$. These data are considered as a robust indication of the re-burial of the regolith together with its substrate and its volcanic cover. The burial is closely related to the tilting of the preserved stratigraphic sequence formed by the rocks of the Sesia-Lanzo Zone, the regolith, and the rocks of the Biella Volcanic Suite (Lanza, in Schweiz Miner Petrogr MItt 57: 281-290, 1977; Lanza, in Geologishe Rundschau 68: 83-92, 1979). Furthermore, the burial is consistent with this sequence of subaerial
\end{abstract}

N. Kapferer $(\bowtie) \cdot$ I. Mercolli

Institute of Geological Sciences, University of Bern,

Baltzerstrasse 1+3, 3012 Bern, Switzerland

e-mail: kapferer@geo.unibe.ch

A. Berger

Institut for Geografi og Geologi, Københavns Universitet,

Øster Voldgade 10, 1350 København K, Denmark rocks being very close to the intrusion depth of the Valle del Cervo Pluton at the time of its emplacement (4-7 km; Zanoni et al., in Rend Online SGI Note Brevi 1: 199-202, 2008; Zanoni et al., in Int Geol Rev 52: 1244-1267, 2010 and references therein).

Keywords Regolith · Paleosurface · Sesia-Lanzo Zone

\section{Introduction}

The understanding of near-surface tectonics and paleoenvironmental conditions requires a detailed investigation into preserved paleosurfaces. The preservation of surface rocks and their possible interaction with the biosphere and/ or the surface water provide the potential for the reconstruction of paleotemperatures and/or paleotopography (e.g., Leier et al. 2009; Kent-Corson et al. 2009). Such a situation exists near Biella, in the Western Alps, on top of the Sesia-Lanzo Zone, which consists of eclogitic continental crust that underwent subduction in late Cretaceous and early Tertiary times (e.g., Konrad-Schmolke et al. 2006; Babist et al. 2006 and literature therein). Any surface of geological age will be eroded away if it remains unprotected. One aim of this work is to reconstruct environmental conditions responsible for the preservation of the paleosurface in the studied area. Field observations and mineralogical data indicate a complex history of the regolith after its formation. Based on microstructural, mineralchemical data, illite and chlorite thermometry, stable isotope compositions of carbonates, and density estimations, we will illustrate the changes affecting the regolith. These changes are then interpreted in terms of post-emplacement evolution of this paleosurface and of the closely related rocks of Sesia-Lanzo Zone and Biella Volcanic Suite. 


\section{Geological setting}

The study area is located northwest of Biella, a town in the Piemonte about $50 \mathrm{~km}$ northeast of Turin. In this area, Oligocene, syn-orogenic volcanic and plutonic rocks outcrop together with high-pressure metamorphic rocks of the Sesia-Lanzo Zone in a narrow region (Fig. 1).

The Periadriatic Lineament, a first-order boundary in the Alps (e.g., Schmid et al. 1989), transects the study area and separates the Sesia-Lanzo Zone from the adjacent IvreaVerbano Zone. This section of the Periadriatic Lineament is called the Canavese Line and has already been investigated from different points of view (Schmid et al. 1989; Zingg and Hunziker 1990; Handy et al. 2005). Within the studied area, a unit of variable thickness (10-200 m) consisting of a tectonic mélange of lithologically heterogeneous and steeply dipping, strongly deformed rocks (cataclastic rocks, mylonites and locally fault gouge) crops out along the Canavese Line.

The Sesia-Lanzo Zone occurs to the northwest of the Canavese Line and consists of a fragment of continental crust derived from the Adria Plate (e.g., Dal Piaz 1999). It forms a lenticular body, oriented SW-NE, between the Canavese Line in the south and the Piemonte ophiolite nappes to the north. Based upon variations in lithology and metamorphic history, the Sesia-Lanzo Zone has been divided into two tectonic units (Compagnoni 1977). The upper unit (the II Dioritic Kinzingitic Zone) shows a dominant metamorphic overprint under amphibolite to granulite facies conditions of pre-Alpine age. The lower unit is divided into two metamorphic complexes that preserve a pervasive Alpine metamorphic overprint: The Gneiss Minuti Complex and the Eclogitic Micaschist Complex. The Eclogitic Micaschist Complex is one of the
Fig. 1 Geological sketch map of the Valle del Cervo area (compiled after Malaroda 1966; Callegari et al. 2004;

Bigioggero et al. 1994; Rossetti et al. 2007; Zanoni et al. 2008). The profile lines of Sect. " 2 (a) and 2 (b)" are shown. In the inset, geological units in the Western Alps. The black rectangle illustrates the position of the study area

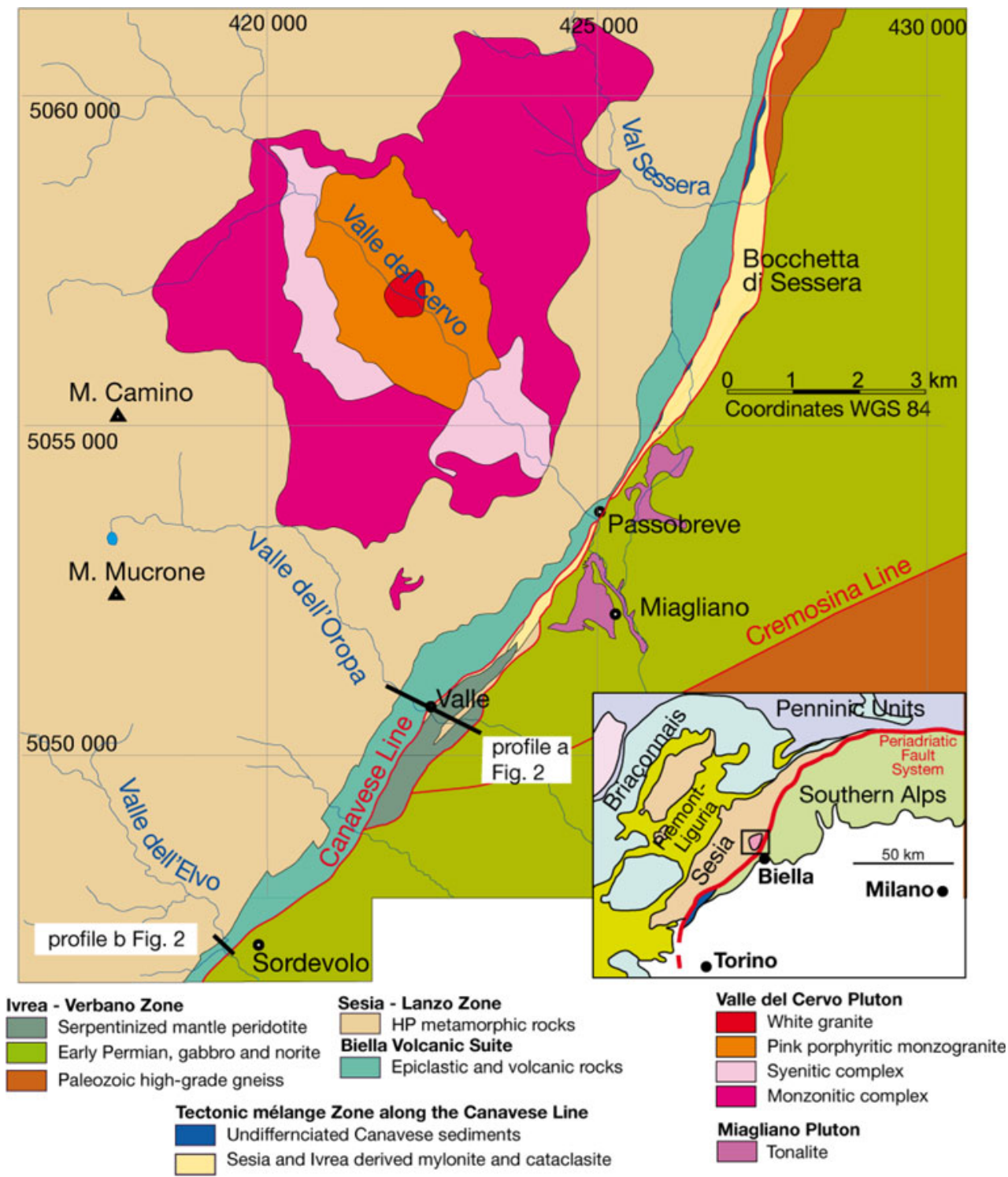


best-preserved examples of continental crust that underwent eclogite-facies metamorphism (Compagnoni 1977; Pognante et al. 1987; Pognante 1991; Konrad-Schmolke et al. 2006: for recent summaries see Goffé et al. 2004; Bousquet et al. 2004 and references therein). The age of the Alpine eclogite-facies metamorphism is suggested to be Upper Cretaceous (65 Ma, Zircon SHRIMP; Rubatto et al. 1999). The high-pressure assemblages are overprinted by greenschist- and/or blueschist-facies assemblages (e.g., Pognante 1991).

Volcano-sedimentary rocks lie on top of the rocks of the Eclogitic Micaschist Complex and are restricted to a narrow belt (ca. $20 \mathrm{~km}$ long and of variable thickness; up to $1 \mathrm{~km}$ ) along the Canavese Line between Donato and the Val Sessera (e.g., Callegari et al. 2004). Frequently, the epiclastic members of the Biella Volcanic Suite contain components of the underlying rocks of the Sesia-Lanzo Zone. The composition of the volcanic rocks ranges from basalt to andesite in the high-K calc-alkaline suite and from trachyandesite to trachydacite in the shoshonitic suite (Callegari et al. 2004).

Approximately $15 \mathrm{~km}$ north of Biella, the Valle del Cervo Pluton ("Biella Pluton") intruded the high-pressure metamorphic rocks of the Sesia-Lanzo Zone (Beccaluva et al. 1985). The intrusion is dated at $31 \pm 0.2 \mathrm{Ma}$ (Romer et al. 1996) and induced contact metamorphism in the country rocks (e.g., Zanoni et al. 2008, 2010 and literature therein). Investigations into the contact aureole indicate an intrusion depth of 4-7 km for the pluton (e.g., Zanoni et al. 2008, 2010 and literature therein). Furthermore, it sustained a hydrothermal system, characterized by a complex vein system, which affected both the rocks of the SesiaLanzo Zone and its volcano-sedimentary cover (Bernardelli et al. 2000; Rossetti et al. 2007).

The Ivrea-Verbano Zone is exposed southeast of the Canavese Line and forms a part of the Southern Alps which was only weakly affected by the Alpine Orogeny. The Ivrea-Verbano Zone in this area consists of basic Permian intrusions (Bertolani 1959; Rivalenti et al. 1975) and their Paleozoic high-metamorphic country rocks (Kinzigite;
Bertolani 1954). A remarkably strong positive gravity anomaly, the "Ivrea Body", underlies this portion of the Ivrea-Verbano Zone (Vecchia 1968; Berckhemer 1968; Giese 1968). Close to the Canavese Line, and in the tectonic mélange zone, serpentinites occur locally.

\section{The regolith as a boundary between the Sesia-Lanzo Zone and its volcano-sedimentary cover}

The cover of the Sesia-Lanzo Zone has been discussed in several different ways in the literature. Bianchi and Dal Piaz (1963) characterized it as a complex volcanic sequence of porphyries, conglomerates, volcanic breccia, and thin tuffitic layers. They observed inclusions of the Eclogitic Micaschist within the volcano-sedimentary unit and assumed a Permian age for the porphyries. Carraro (1966) described the basal tuffites at Sordevolo NW Biella with their inclusions of the Eclogitic Micaschist Complex as a non-metamorphic psephitic continental series of Upper Carboniferous age. In contrast, Scheuring et al. (1974) estimated a Tertiary age for the volcaniclastic rocks based on paleobotanical data and measured K-Ar total rock ages of the andesitic volcanic rocks between 29 and $33 \mathrm{Ma}$.

Two profiles of the transition between the Sesia-Lanzo Zone and the Ivrea-Verbano Zone in Valle dell'Oropa, and along the Elvo River near Sordevolo (Fig. 2a, b), illustrate the relationship between the rocks of the Sesia-Lanzo Zone and its volcano-sedimentary cover, the Biella Volcanic Suite (BVS). The major portion of the BVS consists of epiclastic rocks, and minor massive lava flows, restricted to the area of Bocchetta di Sessera. The epiclastic rocks are represented by conglomerates containing well-rounded components of volcanic rocks and various amounts of rocks of the Sesia-Lanzo Zone, as well as conglomerates containing exclusively volcanic components. Locally, primary layering structures can be observed. These are characterized by changes in the relative abundance and size of the components of the volcanic rocks and of the rocks of the Sesia-Lanzo Zone, as well as by a slight alignment
Fig. 2 Sections between the Ivrea-Verbano Zone and the Sesia-Lanzo Zone. a Valle dell'Oropa section; and b Valle dell'Elvo section (reconstructed after Carraro 1966)

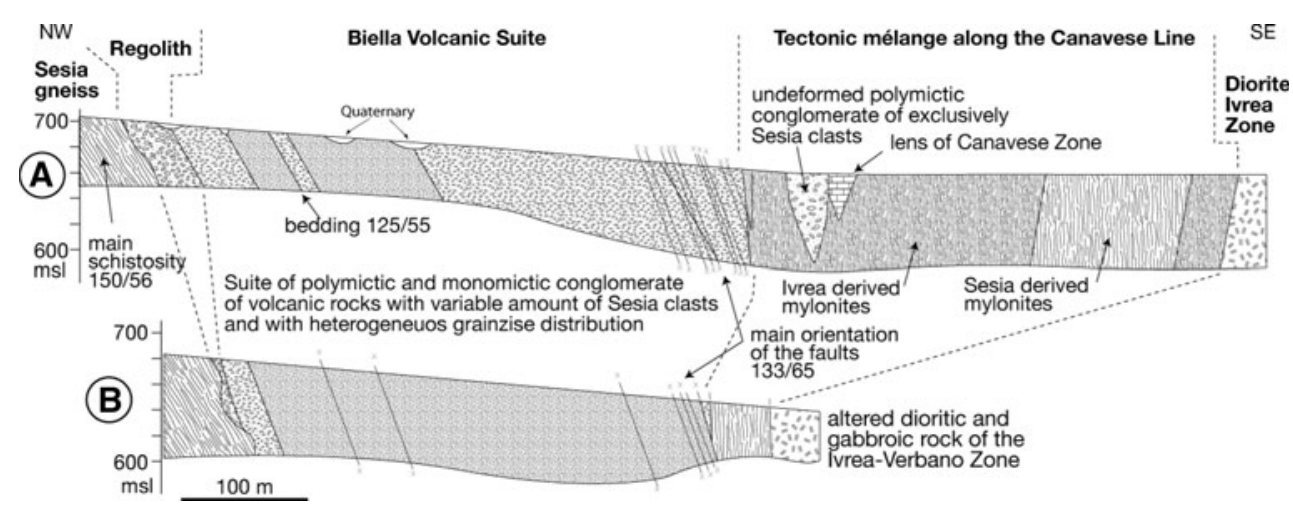


of the elongated constituents. The layering structures are oriented more or less parallel to the foliation of the underlying rocks of the Sesia-Lanzo Zone and are steeply dipping to the southeast. Assuming a subhorizontal emplacement of the epiclastic rocks, both the BVS and the subjacent rocks of the Sesia-Lanzo Zone must have been tilted after the emplacement of the rocks of the BVS. The field observations are confirmed by paleomagnetic data (Lanza 1977, 1979), which definitively shows tilting of ca. $60^{\circ}$ around flat-lying axes striking $\mathrm{N} 20^{\circ}$ for this portion of the Sesia-Lanzo Zone. The regolith itself lacks internal fabrics. No tectonic overprint affected the original contact between the regolith, the rocks of the Sesia-Lanzo Zone and the BVS, whereas the BVS is discordantly truncated by strongly deformed rocks along the Canavese Line.

In the following sections, we focus on the boundary between rocks of the Sesia-Lanzo Zone and the overlying BVS. A layer revealing the characteristics of a regolith was found at the contact between the two units. The term "regolith" is derived from the Greek words "regos", meaning blanket or cover, and "lithos", meaning rock or stone, and was firstly defined by Merrill (1897). It is a layer of fragmental rock material that has undergone little transport. Taylor and Eggleton (2001) postulated important factors regarding regolith development such as tectonic activity, topographic position, landscape processes including erosion and deposition, drainage conditions, and biological activity. The regolith is characterized by the clays produced during weathering, the rock structure, the state of oxidation of iron, porosity, and patterns of biotic activity.

\section{Field observations}

The investigated regolith is exposed in several outcrops in Passobreve (Valle del Cervo), Valle (Valle dell'Oropa), Bocchetta di Sessera, Val Sessera, and Valle dell'Elvo near Sordevolo (Fig. 1) between the underlying Eclogitic Micaschist Complex and the overlying BVS. A complete sequence of the rocks of the Sesia-Lanzo Zone with the overlying regolith and BVS, without any tectonic perturbation, outcrops near Sordevolo (Valle dell'Elvo; Fig. 3a). In Valle dell'Oropa, the direct contact between the regolith and the rocks of the BVS is covered by scree. In Valle del Cervo, Bocchetta di Sessera, and Val Sessera, the original attitude has been disturbed by later brittle faulting with a minor offset. The thickness of the regolith is usually on a decimeter- to meter-scale.

The regolith can be described as a consolidated monomictic breccia consisting of fragments of the high-pressure metamorphic rocks of the Sesia-Lanzo Zone, without any volcanic constituents (Fig. 3c). The breccia is ungraded and unsorted, and either matrix- or grain-supported. The individual fragments within the breccia lack any preferred orientation and are incorporated into a fine-grained reddish matrix. The composition of the angular sub-mm- to several $\mathrm{dm}$-sized fragments varies between metapelite, gneiss, feldspar-rich quartzite, and sparse metabasic rocks. This suggests a development of the regolith mainly through in situ mechanical disintegration of the rocks of the SesiaLanzo Zone. The clasts often indicate that after fragmentation, the single components have been only slightly shifted against each other without a relevant transport component.

\section{Microscopical features and mineralogy of the regolith}

Analytical methods

Alteration petrographic studies were performed on thin sections with an optical polarizing microscope. Detailed observations were achieved using a Zeiss EVO 50 (with a Sapphire light element EDX detector) scanning electron microscope (SEM) and a Micro-Raman spectrometer.

Chlorite, clay minerals, and carbonate were analysed with a JEOL JXA-8200 electron microprobe at the University of Bern. Operating conditions for chlorite and clay measurements were $15 \mathrm{kV}$ acceleration voltage, beam current $8 \mathrm{nA}$ and a $10 \mu \mathrm{m}$ beam diameter, and with a beam current $5 \mathrm{nA}$ and a $7 \mathrm{~mm}$ beam diameter used for carbonates. The elements were measured for $20 \mathrm{~s}$ on the peak as well as background. Natural and synthetic minerals were used as standards.

For XRD analyses of chlorite and clay minerals, whiteto-pale-green rock portions were selected by hand. The particles had previously been ground in the agate mortar to a clay-size fraction. Mixtures of powder and distilled water were dispersed ultrasonically, pipetted, and air-dried on glass slides to produce thin-layered, orientated aggregates. In order to avoid the (partial) dissolution of chlorite, no acid treatment was applied. Glycolation of an aliquot of the samples was undertaken for eight hours at $50^{\circ} \mathrm{C}$ for the detection of swellable minerals. XRD analyses were undertaken with a Philips PW 1830 diffractometer using $\mathrm{CuK}_{\alpha}$ radiation $(40 \mathrm{kV}, 30 \mathrm{~mA}$, divergence and detector slits of $0.02^{\circ}$, goniometer speed of $0.004 \%$ s). The data analysis was performed using the X'Pert Quantify software, version $1.0 \mathrm{c}$.

The $\mathrm{C}$ and $\mathrm{O}$ isotope composition of carbonate was measured on a Finnigan Delta V Advantage mass spectrometer equipped with an automated carbonate preparation system (Gas Bench-II). The isotope compositions are expressed as $\delta^{18} \mathrm{O}$ values relative to the VSMOW standard and as $\delta^{13} \mathrm{C}$ values relative to the VPDB standard; standardization was accomplished using international standards 
Fig. 3 Field observations and microstructural characteristics of the regolith and its volcanosedimentary cover. a Field photograph of the stratigraphic sequence of the rocks of the Sesia-Lanzo Zone to the overlying regolith and epiclastic rocks of the BVS in Sordevolo (note hammer for scale); $\mathbf{b}$ field photograph of the epiclastic rocks of the BVS represented by a conglomerate containing wellrounded components of volcanic rocks and of rocks of the Sesia-Lanzo Zone (note coin for scale); c field photograph of the regolith represented by a breccia consisting exclusively of fragments of the rocks of the Sesia-Lanzo Zone (note hammer for scale); d thin section of newly developed phases such as chlorite, illite, and hematite in the matrix of the regolith. Plane-polarized light, 200- $\mu \mathrm{m}$ scale bar, mineral abbreviations after Kretz 1983; e thin section of chlorite which overgrew primary minerals and illite, hematite and lepidocrocite filling matrix cavities within the regolith. Plane-polarized light, 200- $\mu \mathrm{m}$ scale bar. f Thin-section of the microstructural relationship between polyphase carbonatic veins, Sordevolo
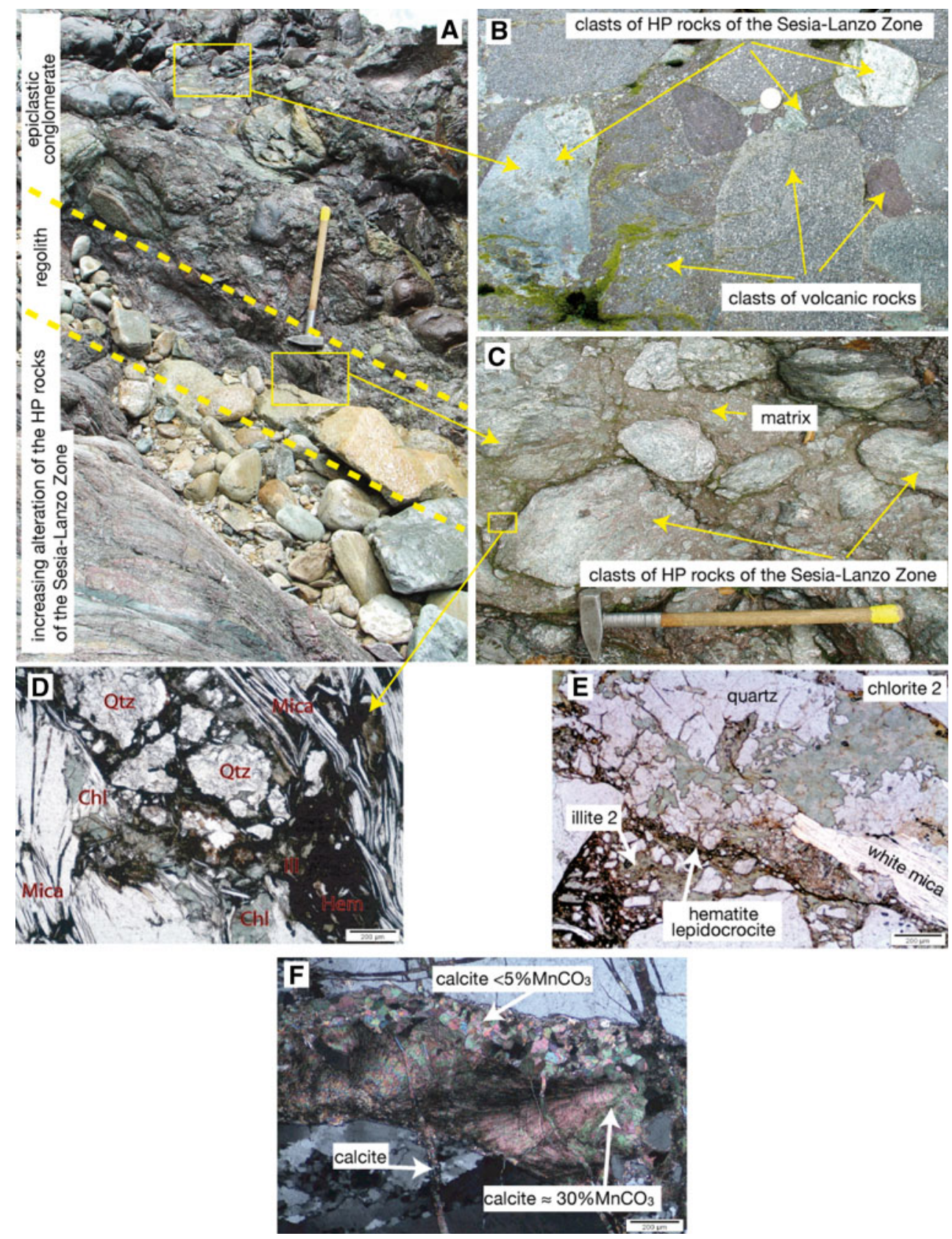

NBS 19, NBS 18, and an internal house standard. The longterm precision of $\delta^{13} \mathrm{C}$ and $\delta^{18} \mathrm{O}$ is 0.05 and $0.07 \%$ ( $1 \sigma$-error; $n=1,390)$, respectively.

The regolith consists of fragments and individual minerals of the underlying high-pressure metamorphic rocks of the Sesia-Lanzo Zone: such as quartz, feldspar, mica, garnet, and rutile (Fig. 3d). The amount of matrix within the breccia is extremely variable $(0-20 \%)$ at the outcrop scale, as well as between the different outcrops. The finegrained matrix is predominantly composed of detrital quartz, feldspar, and mica derived from the in situ fragmentation of the rock-forming minerals of the rocks of the
Sesia-Lanzo Zone. These primary minerals within the regolith are either unaltered or partially replaced by chlorite, clay minerals, and calcite (Fig. 3e). The fine-grained matrix between the individual components of the breccia appears as connected micro-vein networks with a highly variable width and diffuse boundaries. Cavities within the matrix are partially filled with differing amounts of newly developed phases such as chlorite, clay minerals, carbonates, hematite, lepidocrocite, and authigenic quartz (Fig. 3d, e). No organic matter was found. The newly developed phases within the matrix normally do not exceed the clay grain size. Therefore, it is difficult to distinguish 
clearly their mutual textural relationships (definition of mineral assemblages). When possible, the newly developed phases were identified by microscopical means, microprobe analysis, and micro-Raman spectrometry. In addition, X-ray diffractometry was used for the identification of these phases and their crystallographic characteristics. The use of the XRD technique requires the extraction by drilling of a minimal aliquote (in some cases only few milligrams) of the analysing material from the sample. This destructive method only allows the determination of the bulk mineralogical composition of the drilled aliquot and, by special preparation, of the crystallographic characteristics of some of the phases but inhibits the reconstruction of the microstructural relationships. Only veins are easily distinguished from the above-mentioned void fillings as they crosscut the whole rock (fragments as well as matrix of the regolith) discordantly and have definite boundaries (Fig. 3f). Nearly all these veins contain carbonates and/or quartz.

In order to enhance the scarce mineralogical data of the regolith itself (due to the scarcity of outcrops, the reduced thickness of the regolith, the small amount of the newly developed phases and their extremely reduced size), we have added data on the post-emplacement alteration of the rocks of the BVS. This procedure is legitimate because the regolith and the rocks of the BVS have suffered the same type of alteration history since their common (in space and time) formation.
Chlorite

Chlorite occurring within the regolith has a wide range of both chemical composition and textures (Table 1). The composition of chlorite that overgrew primary minerals such as garnet, amphibole, mica, and feldspar can be considered as intermediate between ripidolite, pychnochlorite, and brunsvigite (Fig. 4). The silicon content ranges between 5.25 and 6.02 atoms p.f.u., the $\mathrm{Fe} /(\mathrm{Fe}+\mathrm{Mg})$ ratio between 0.46 and 0.71 atoms p.f.u. Chlorite developed in vesicles in the matrix plots in the ripidolite, pychnochlorite, brunsvigite, and diabanite field (Fig. 4). It is characterized by a wide range of silicon content $(5.26<\mathrm{Si}<6.66$ atoms p.f.u $)$ and a $\mathrm{Fe} /(\mathrm{Fe}+\mathrm{Mg})$ ratio between 0.38 and 0.65 atoms p.f.u.

Illite

The microscopical identification of different types of illite and their distribution within the regolith and the rocks of the BVS is impossible. The presence of illite and chlorite within the regolith and the overlying rocks of the BVS was determined by X-ray diffractometry (XRD). The results indicate coexistence of different phases within a drilled volume of each sample. A mixture of different generations or textural types cannot be avoided using this method. Even SEM observation could not really help to unravel the relationships between these phases. Measurements on

Table 1 Representative electron microprobe analyses of chlorite

\begin{tabular}{|c|c|c|c|c|c|c|c|c|}
\hline & 1 & 2 & 3 & 4 & 5 & 6 & 7 & 8 \\
\hline $\mathrm{SiO}_{2}$ & 24.27 & 28.99 & 26.29 & 25.19 & 26.62 & 30.01 & 30.79 & 33.01 \\
\hline $\mathrm{TiO}_{2}$ & 0.02 & 0.05 & 0.01 & 3.50 & 0.00 & 0.01 & 0.04 & 0.02 \\
\hline $\mathrm{Al}_{2} \mathrm{O}_{3}$ & 23.59 & 19.48 & 22.53 & 21.48 & 22.91 & 22.53 & 17.26 & 17.42 \\
\hline $\mathrm{FeO}$ & 33.13 & 23.43 & 29.01 & 25.62 & 28.24 & 22.69 & 20.66 & 20.38 \\
\hline $\mathrm{MnO}$ & 0.24 & 0.38 & 0.14 & 0.14 & 0.21 & 0.13 & 0.15 & 0.19 \\
\hline $\mathrm{MgO}$ & 7.55 & 15.55 & 9.96 & 12.70 & 9.84 & 11.89 & 18.40 & 16.64 \\
\hline Total & 88.80 & 87.87 & 87.94 & 88.63 & 87.82 & 87.26 & 87.30 & 87.66 \\
\hline \multicolumn{9}{|c|}{ Cations per 28 oxygens } \\
\hline $\mathrm{Si}$ & 5.250 & 5.987 & 5.592 & 5.260 & 5.638 & 6.148 & 6.294 & 6.657 \\
\hline $\mathrm{Al}^{\mathrm{IV}}$ & 2.750 & 2.013 & 2.408 & 2.740 & 2.362 & 1.852 & 1.706 & 1.343 \\
\hline $\mathrm{Al}^{\mathrm{VI}}$ & 3.265 & 2.729 & 3.240 & 2.547 & 3.357 & 3.588 & 2.452 & 2.797 \\
\hline $\mathrm{Ti}$ & 0.004 & 0.007 & 0.002 & 0.550 & 0.000 & 0.002 & 0.005 & 0.003 \\
\hline $\mathrm{Fe}$ & 5.993 & 4.046 & 5.159 & 4.473 & 5.001 & 3.887 & 3.531 & 3.436 \\
\hline $\mathrm{Mn}$ & 0.043 & 0.066 & 0.024 & 0.025 & 0.038 & 0.023 & 0.027 & 0.032 \\
\hline $\mathrm{Mg}$ & 2.434 & 4.786 & 3.157 & 3.953 & 3.106 & 3.630 & 5.606 & 5.001 \\
\hline Total & 19.739 & 19.635 & 19.583 & 19.547 & 19.503 & 19.130 & 19.622 & 19.270 \\
\hline $\mathrm{X}_{\mathrm{Fe}}$ & 0.711 & 0.458 & 0.620 & 0.531 & 0.617 & 0.517 & 0.386 & 0.407 \\
\hline
\end{tabular}

Chlorite replacing primary minerals of the rocks of the Sesia-Lanzo Zone: analyses 1-3; Chlorite occurring in cavities in the matrix of the regolith: analyses $4-8 . \mathrm{X}_{\mathrm{Fe}}=\mathrm{Fe}_{\mathrm{tot}} /\left(\mathrm{Fe}_{\mathrm{tot}}+\mathrm{Mg}\right)$ 


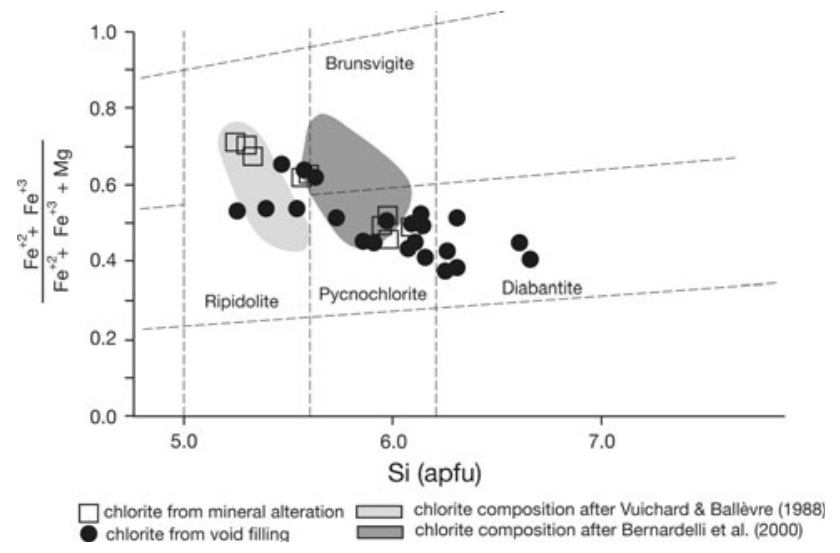

Fig. 4 Chlorite compositions in a diagram of Hey 1954. Open rectangle: Chlorite which overgrew primary minerals of the rocks of the Sesia-Lanzo Zone; Filled circle: Chlorite occurring in cavities in the matrix of the regolith; Light-gray domain: Chlorite composition after Vuichard and Ballèvre (1988); Dark-gray domain: Chlorite composition after Bernardelli et al. (2000)

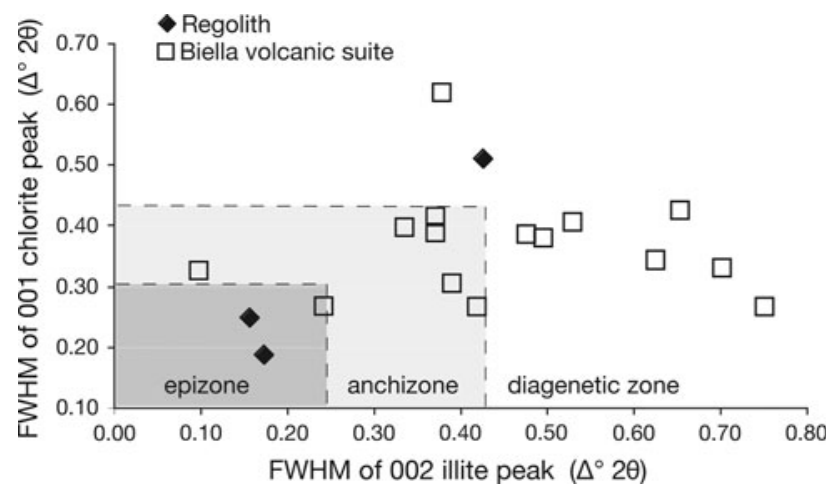

Fig. 5 Relationships between the full with at half maximum (FWHM) of the illite 10 - $\AA$ peak $\left(\mathrm{Ill}_{002}\right)$ versus the FWHM of the chlorite 14- $\AA$ peak $\left(\mathrm{Chl}_{001}\right)$. Filled diamond: Illite and chlorite occurring within the regolith; Open rectangle: Illite and chlorite occurring within the rocks of the BVS. Subdivision of zones with increasing metamorphic grade with FWHM of illite according to Kübler (1967) and FWHM of chlorite according to Arkai (1991)

air-dried and ethylene-glycol-solvated samples indicate a lack of interlayers of smectite and vermiculite. Figure 5 shows the full width at half maximum (FWHM) of the illite $10-\AA$ peak $\left(\mathrm{Ill}_{002}\right)$ versus the FWHM of the chlorite $14-\AA$ peak $\left(\mathrm{Chl}_{001}\right)$ of the regolith and rocks of the BVS. Kübler (1967) used FWHM determinations of the illite 10- $\AA$ peak to distinguish three zones with increasing metamorphic grade (diagenetic zone, anchizone, and epizone). The anchizone in the Alps (with FWHM of the illite 10- $\AA$ peak between 0.25 and $0.42^{\circ} 2 \theta$ ) corresponds approximately to the temperature range between 200 and $300^{\circ} \mathrm{C}$ (Frey 1986). Arkai (1991) defined the anchizone with FWHM of the chlorite $14-\AA$ peak between 0.31 and $0.43^{\circ} 2 \theta$. The XRD analyses of the regolith indicate two types of illite with FWHM $<0.25^{\circ} 2 \theta$ and $>0.42^{\circ} 2 \theta$. The FWHM of illite and chlorite occurring in the epiclastic rocks of the BVS indicates anchizonal conditions.

\section{Carbonates}

Mineralogically and microstructurally different types of carbonates occur within the regolith. Void-filling sparry calcite and extremely fine-grained carbonates overgrowing rock fragments or individual minerals within the breccia are the most typical microstructural types. Locally, finely dispersed calcite yields cement formation and binds the coarser-grained matrix and individual minerals. Microprobe analyses confirm that calcite is the main constituent of these cements. Carbonate veins discordantly crosscutting the regolith are filled with calcite, Mn-bearing calcite, dolomite, and ankerite (Fig. 6). In Valle dell'Elvo, carbonates with various textures and chemical compositions occur within the same vein. Fan-shaped calcite with $30-35 \% \mathrm{MnCO}_{3}$ is overgrown by relatively smaller sparry calcite with $\leq 5 \% \quad \mathrm{MnCO}_{3}$. These veins, as well as the fragments of the breccia, are often crosscut by more thin last stage veins filled with pure calcite (Fig. 3f). In Valle dell'Oropa, vein fillings predominantly consist of sparry dolomite with $\leq 2 \% \mathrm{FeCO}_{3}$ associated with fine-grained ankerite with $\geq 10 \% \mathrm{FeCO}_{3}$.

To test the assumption of a similar development of the alteration of the rocks of the BVS, the regolith, and the adjacent rocks of the Sesia-Lanzo Zone, stable isotope compositions of carbonates were analysed in order to reconstruct the formation conditions of the carbonates occurring within the stratigraphic sequence (Fig. 7). One calcite and one ankerite vein crosscutting the rocks of the Sesia-Lanzo Zone in the region of Passobreve (Valle del Cervo) (Diamond, pers. comm.) have been added to our data set.

Except from a calcite vein crosscutting the rocks of the Sesia-Lanzo Zone with a $\delta^{18} \mathrm{O}_{\text {vSMOw value of } 4.5 \% \text {, the }}$ carbonates in the regolith, the epiclastic rocks of the BVS

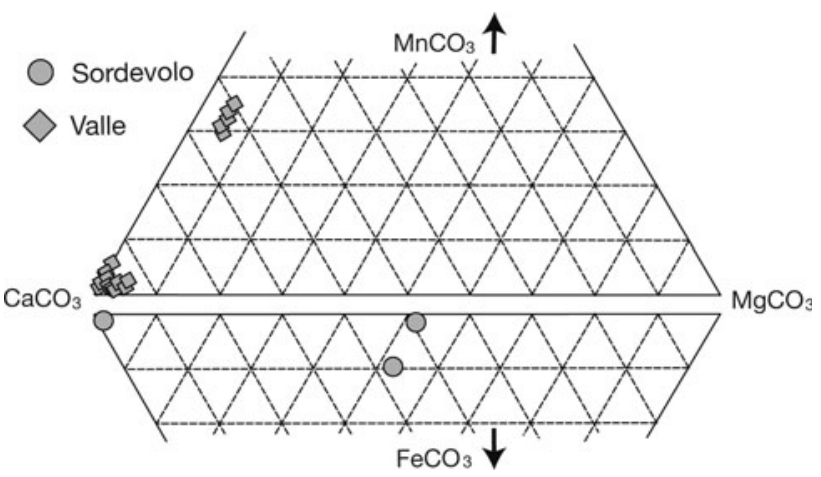

Fig. 6 Carbonate compositions in two combined triangle diagrams. Filled rectangle: samples from Valle (Valle dell'Oropa); Filled circle: samples from Sordevolo (Valle dell'Elvo) 


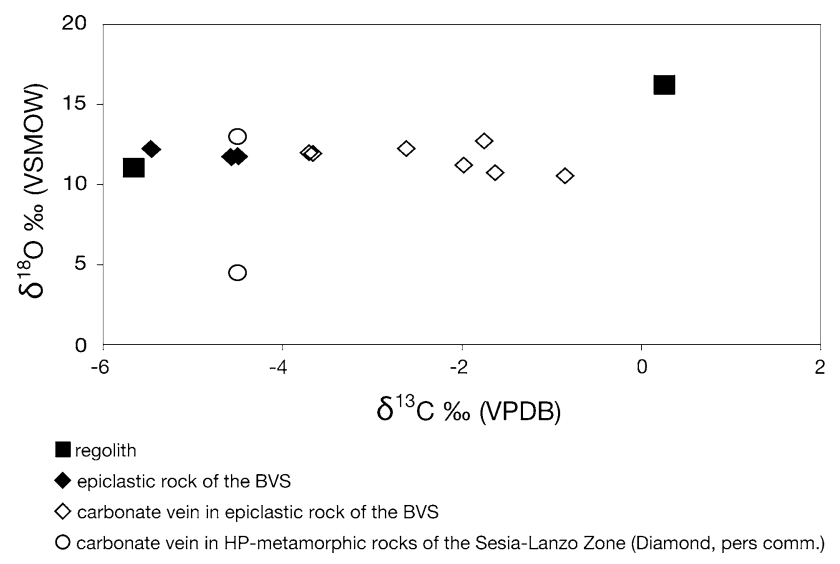

Fig. 7 The $\delta^{13} \mathrm{C}_{\mathrm{VPDB}}$ and $\delta^{18} \mathrm{O}_{\mathrm{VS}}$ ow composition of the regolith, epiclastic rocks of the BVS and veins

and veins show minor variations. The minimal and maximal $\delta^{13} \mathrm{C}_{\mathrm{VPDB}}$ values for all different rock types and veins are fixed with $\delta^{13} \mathrm{C}_{\mathrm{VPDB}}$ values for carbonate in the regolith ranging from -5.7 to $0.3 \%$ o for all outcrops.

\section{Quartz}

In contrast to detrital quartz coming from the underlying rocks of the Sesia-Lanzo Zone, authigenic quartz occurring in cavities in the matrix of the regolith is characterized by a straight extinction and is often associated with other newly developed phases. Locally, rock fragments and individual minerals of the breccia are cemented by fine-grained quartz. Quartz also occurs as vein filling.

Hematite and lepidocrocite

Hematite and lepidocrocite (determined by Micro-Raman spectroscopy), finely dispersed in the matrix, give the regolith its reddish color and are often associated with chlorite (Fig. 3e).

\section{Density estimations along a profile}

Analytical methods

Five samples of undisturbed metamorphic rocks and one regolith were chosen in a profile perpendicular to the paleosurface in Sordevolo for density estimations. Twenty to thirty grams of rock fragments of each sample were heated in air at $100^{\circ} \mathrm{C}$ to constant weight. The volume of each sample was measured using the Archimedes method, weighing in air and in mercury. The weight of mercury lost was recorded.

A complete stratigraphic sequence from the high-pressure metamorphic rocks of the Sesia-Lanzo Zone to the

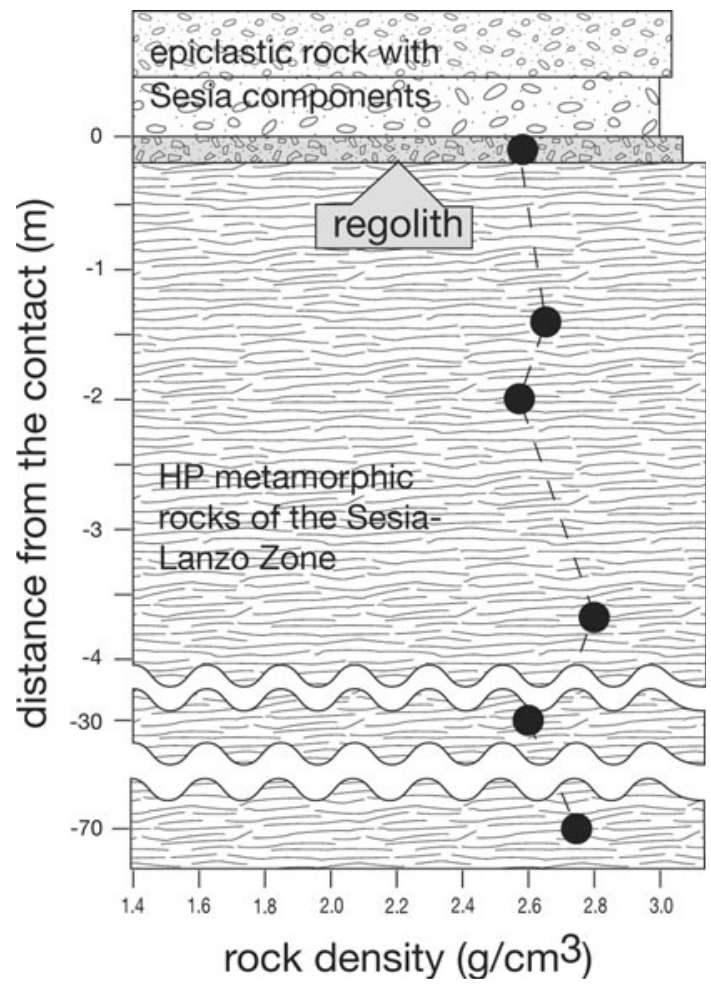

Fig. 8 Density estimations for the regolith and the underlying rocks of the Sesia-Lanzo Zone in a profile perpendicular to the paleosurface in Sordevolo (Valle dell'Elvo)

regolith and the overlying epiclastic rocks of the BVS is exposed along the river Elvo near Sordevolo (Figs. 2b and 3a). This sequence is the best-preserved example of the lack of any later tectonic overprint of the sequence after the regolith formation and deposition of the epiclastic rocks of the BVS. In a profile perpendicular to the paleosurface, six samples from the undisturbed metamorphic rocks and the regolith were chosen for density determinations by $\mathrm{Hg}$ porosimetry (Fig. 8). The density of the investigated regolith is $2.6 \mathrm{~g} / \mathrm{cm}^{3}$ and is similar to the average density of the rocks of the Sesia-Lanzo Zone along the profile. This confirms the field and microstructural observations suggesting a development of the regolith mainly through in situ mechanical disintegration of the rocks of the Sesia-Lanzo Zone. The similar densities indicate that the fragmentation of the basement rocks had no significant effect on the density and that only a small amount of alteration minerals with low densities has been formed within the regolith.

\section{Discussion}

Interpretation of the mineralogy of the regolith

Field and microstructural observations, mineral chemical data, illite and chlorite thermometry as well as stable 
isotope compositions of carbonates have been used to decipher the mineralogical evolution of the regolith. However, the scarcity of outcrops, the clay size of the alteration minerals, and the mixture of authigenic minerals with fragments of low-grade metamorphic minerals related to the pre-Eocene cooling history of the Sesia-Lanzo Zone (e.g., Pognante 1991) make the interpretation of the data difficult.

A long list of possible (and probable) processes involving alteration of the regolith after its formation has to be considered: (1) Alteration occurring when the regolith was exposed at the surface shortly after formation; (2) Subsurface very low-grade metamorphic recrystallization or authigenic crystallization during the tilting and consequent burial of the regolith (and the entire related stratigraphic sequence); (3) Contact metamorphism and hydrothermal alteration of the regolith induced by the emplacement of the Valle del Cervo Pluton (Bigioggero et al. 1994; Bernardelli et al. 2000; Zanoni et al. 2008, 2010); (4) Any kind of transformation related to the residence of the sequence at uppermost crustal levels during the most of Neogene. Besides the metamorphic re-equilibration in response to changing PTX conditions, this includes hydrothermal circulation along a large number of brittle structures affecting this crustal block (from the last post-Eocene movements along the Canavese Line to the Holocene post-glacial relaxation); (5) Finally, it cannot be excluded that some of the described features could have been formed during the recent re-exposition at the surface.

It is impossible to clearly relate any mineral alteration, void filling, and vein to one of the events listed above. Our aim is to discuss some arguments that can help to unravel the post-emplacement evolution of the regolith and its consequences on the tectonic evolution of this portion of Sesia-Lanzo Zone.

\section{Chlorite}

Figure 4 illustrates the variation of the chemical composition of chlorite occurring in the regolith. The regolith mainly consists of fragments and individual minerals of the high-pressure metamorphic rocks of the Sesia-Lanzo Zone, which are overprinted by greenschist- and/or blueschistfacies assemblages (e.g., Pognante 1991). Therefore, a part of the chlorite that overgrew primary minerals within the regolith can be related to the alteration of the HP minerals of the rocks of the Sesia-Lanzo Zone during its cooling history (e.g., Pognante 1991). Figure 4 shows that chlorite of ripidolite composition, which occurs as an alteration product of primary minerals within the regolith, corresponds to the chlorite composition described by Vuichard and Ballèvre (1988) for the retrograde metamorphism in the eclogitic pelitic rocks of the Sesia-Lanzo Zone.
Various mineralized hydrothermal veins that probably relate to the intrusion of the Valle del Cervo Pluton, which outcrop near Passobreve in Valle del Cervo (a few hundred meters away from the regolith), also have comparable chlorite compositions (Bernardelli et al. 2000). All other chlorite compositions must be assumed to represent chlorite crystallizing during one of the events described above.

\section{Illite}

XRD analyses indicate the occurrence of illite within the regolith and the rocks of the BVS. Based on FWHM estimations, two groups of illite can be distinguished (Fig. 5). Illite showing tightened diffraction peaks (FWHM $<$ $0.25^{\circ} 2 \theta$ ) formed under epizonal conditions, and illite characterized by broader diffraction peaks (FWHM > $0.42^{\circ} 2 \theta$ ) indicates diagenetic conditions. Illite referring to epizonal temperatures may be interpreted as a result of the mechanical disintegration of the retrograde altered primary phengite of the high-pressure metamorphic rocks of the Sesia-Lanzo Zone. The second type, formed at temperatures lower than $300^{\circ} \mathrm{C}$, according to the temperature zones suggested by Frey (1986), may have formed after the development of the regolith and the emplacement of the rocks of the BVS. Following Arkai (1991), anchizonal and diagenetic conditions for the development of authigenic illite are confirmed by XRD data of coexisting chlorite (Fig. 5). The authigenic illite and chlorite indicate temperatures higher than expected at the surface. This fact was already proposed by Zingg et al. (1976), who interpreted the re-heating of the volcaniclastic rocks as a slight contact metamorphism induced through overriding hot andesite flows. However, except at Bocchetta di Sessera, the rocks of the Sesia-Lanzo Zone and the regolith are covered by epiclastic rocks of the BVS. These polymictic conglomerates, containing well-rounded components of volcanic rocks and of rocks of the Sesia-Lanzo Zone, refer to an alluvial depositional environment. Therefore, a thermal input directly from the volcanic rocks can be excluded. The increase in temperature of the epiclastic rocks of the BVS can be related to the burial of the stratigraphic sequence. A thermal input due to the intrusion of the Valle del Cervo Pluton is realistic, at least for the section along the Valle del Cervo, as all previous authors agree with a contact aureole around the pluton of ca. $1 \mathrm{~km}$ (Zanoni et al. 2008 and references therein), and in Passobreve the regolith is less then $1 \mathrm{~km}$ away from the intrusive contact.

\section{Carbonate}

As for chlorite, the complex chemical compositions and textural characteristics of the carbonates cannot be related precisely to a certain event. Only the ankerite-bearing veins 
crosscutting the regolith in Valle dell'Oropa and Valle del Cervo may be linked to the ankerite-bearing veins described by Bernardelli et al. (2000). These authors suggested, based on arsenopyrite and chlorite geothermometry, temperatures $\geq 250^{\circ} \mathrm{C}$ for these veins which is in agreement with the temperatures obtained by illite and chlorite thermometry.

Stable isotopes of carbonate data

Several processes may be responsible for the formation of carbonates within the regolith and consequently within the epiclastic rocks of the BVS, as well as within veins crosscutting the rocks of the BVS, the regolith, and the adjacent rocks of the Sesia-Lanzo Zone: (1) Carbonate formation under surface conditions by weathering reactions; (2) Carbonate formation by precipitation from river water during the emplacement of the epiclastic volcanic rocks of the BVS on top of the paleosurface. In both these cases, the carbonates would have formed under ambient conditions from meteoric water; (3) Carbonate precipitation from hydrothermal fluids circulating into the uppermost crust (low-grade metamorphism) during the burial of the stratigraphic sequence; (4) Carbonate veins formed by hydrothermal fluids generated by the Valle del Cervo Pluton; (5) Alteration of the regolith and adjacent units by the today's surface water.

A precise correlation between the carbonate formation (not even in a set of veins of the same type) and a distinct geological event is impossible. Neither the formation temperature nor the isotope composition of the carbonate forming fluid is known a priori. However, some qualitative information about the formation temperature of the carbonates can be obtained using the temperature dependence of the oxygen isotope fractionation according to Friedmann and O'Neil (1977). Except for a calcite vein crosscutting the rocks of the Sesia-Lanzo Zone with a $\delta^{18} \mathrm{O}_{\mathrm{vs} \text { sow value of }}$ $4.5 \%$, the carbonates in the regolith, epiclastic rocks of the BVS, and veins were formed under similar temperatures and fluid isotope compositions (Fig. 7). In turn, these carbonates cannot have formed under surface temperature conditions even using a large assumed range of reasonable $\delta^{18} \mathrm{O}_{\text {vSMOW }}$ values for meteoric water between -5 and $-12 \%$ (Clark and Fritz 1997). Combined with the rather narrow range in oxygen isotope compositions of these carbonates, it seems most plausible that the majority of the carbonates developed during the burial of the entire sequence at temperatures higher than $50^{\circ} \mathrm{C}$ or can be related to localized hydrothermal circulation during some punctual geological event as the intrusion of the Valle del Cervo Pluton.

There have been a number of attempts to define isotopic compositions of waters associated with magmatic and metamorphic rocks (Sheppard 1986). For example,
Sheppard (1986) determined $\delta \mathrm{D}$ and $\delta^{18} \mathrm{O}$ values of characteristic waters of different environments and estimated magmatic and metamorphic water fields. Regarding these subdivisions, the estimated isotopic compositions of formation water occurring in carbonates within the regolith and epiclastic rocks of the BVS suggest formation water associated with metamorphic rocks.

The $\delta^{13} \mathrm{C}_{\mathrm{VPDB}}$ values indicate that the carbonates have been formed through inorganic processes. The $\delta^{13} \mathrm{C}_{\mathrm{VPDB}}$ values of carbonates within the regolith, epiclastic rocks of the BVS, and veins, which range from -5.7 to $0.3 \%$, might indicate some open system conditions during carbonate formation (i.e., $\mathrm{CO}_{2}$ degassing), but this would have to be confirmed by additional analyses. The significantly different values in the regolith itself can be explained as a result of $\mathrm{CO}_{2}$ escape in an open system. The effect of $\mathrm{CO}_{2}$ escape in an open system is also reflected by the very different values within the regolith itself.

To conclude: (1) Stable isotopes of carbonates occurring in the regolith and epiclastic rocks of the BVS suggest that these carbonates were formed at temperatures higher than expected at the surface; (2) In combination with the determinations of FWHM of illite and chlorite, the $\delta^{18} \mathrm{O}_{\text {vSMOw }}$ values indicate that the carbonates in the regolith, the epiclastic rocks, and veins equilibrated during the burial of the stratigraphic sequence by hydrothermal fluids.

The evolution of the surface of the Sesia-Lanzo Zone

The development of the regolith on top of the Sesia-Lanzo Zone can be explained by continental processes, such as physical and chemical weathering, erosion, and sediment transport. Field and microstructural observations, as well as density estimations (Fig. 8), suggest regolith formation mainly through in situ mechanical disintegration of the rocks of the Sesia-Lanzo Zone. Generally, rocks weather when they interact with air, water, and biota in the nearsurface environment. The interaction is greatest near the surface and declines with depth. In a typical regolith profile, bulk density progressively decreases in the more highly weathered materials (McNally 1992). According to the nomenclature of McNally (1992), the investigated regolith can be described as a fresh respectively slightly decomposed rock. Alternatively, the high densities could have been the result of elutriation of clay particles within the regolith by the high flow regime during alluvial sedimentation of the epiclastic rocks.

In a typical regolith profile, different zones of weathering can be distinguished (e.g., Ruxton and Berry 1957; Birkeland 1984; Boulangé et al. 1997). The investigated regolith can be regarded as a saprock, the lowermost part in the regolith profile overlying the bedrock (in this case the 
rocks of the Sesia-Lanzo Zone). Within a saprock, corresponding to the first stage of weathering of the regolith, the fabrics and most of the characteristics of the parent rocks are still retained. Weathering is restricted to failure systems like joints and foliations within the bedrock. These features correspond to the described observations of the regolith in the study area.

The upper parts of a typical regolith profile, such as the soil horizon, are missing. No evidence of any paleosoil between the rocks of the Sesia-Lanzo Zone and its volcano-sedimentary cover has been found. In addition, no preserved organic matter can be observed within the regolith. The lack of layers overlying the saprock in the investigated regolith profile can be explained by three different scenarios: (1) The climatic conditions did not permit soil formation; (2) The regolith developed with a soil until the fluvial emplacement of the epiclastic rocks eroded the upper part of the regolith; (3) In a highly erosive environment (steep slopes), the newly formed soil was constantly removed.

Except at Bocchetta di Sessera, the investigated regolith is sealed by the epiclastic rocks of the BVS and is represented by a polymictic conglomerate containing wellrounded components of volcanic rocks and various amounts of rocks of the Sesia-Lanzo Zone (Fig. 3b). These epiclastic rocks have been formed in an alluvial environment proximal to the eruption centers (boulders up to $1 \mathrm{~m}$ in diameter are frequent in the basal layer of the epiclastic rocks).

The lack of important deformation structures between the regolith, the rocks of the Sesia-Lanzo Zone and of the $\mathrm{BVS}$, indicates that this sequence has preserved its original stratigraphic relationships. Therefore, the $\mathrm{K}-\mathrm{Ar}$ total rock ages of the volcanic rocks between 29 and $33 \mathrm{Ma}$ (Scheuring et al. 1974) can be used as a time constraint for the exposure of the rocks of the Sesia-Lanzo Zone at the surface. Zingg et al. (1976) assume that the low-grade metamorphism affecting the rocks of the BVS induced a rejuvenation of the $\mathrm{K}-\mathrm{Ar}$ total rock ages of Scheuring et al. (1974). Consequently, the oldest age of $33 \mathrm{Ma}$ can be considered as the minimum possible age for the emplacement of the volcanic rocks. This implies that the Earliest Rupelian is a minimum age for the exhumation at the surface of this portion of the Sesia-Lanzo Zone and for the regolith formation.

The evolution of the surface of the innermost part of the Sesia-Lanzo Zone begins with the eclogite-facies metamorphism affecting the rocks of the Sesia-Lanzo Zone at $65 \mathrm{Ma}$ (Rubatto et al. 1999). The K-Ar whole rock ages of the volcanic rocks ( $\sim 33 \mathrm{Ma}$; Scheuring et al. 1974) provide evidence that the high-pressure metamorphic rocks of the Sesia-Lanzo Zone had been exposed at the surface in Late Eocene to Early Oligocene. The saprock developed at this time on top of the rocks of the Sesia-Lanzo Zone. The present-day steeply dipping geometry of the stratigraphic sequence, from the rocks of the Sesia-Lanzo Zone to the regolith and the rocks of the BVS, indicates a tilt of the whole sequence. This has been confirmed by paleomagnetic measurements (Lanza 1977, 1979). We suggest that the tilting is closely related to the burial of the earliest Rupelian surface sequence, as demonstrated by illite and chlorite thermometry as well as by the isotopic data of carbonates. These data clearly indicate that the surface conditions were overprinted by anchi-metamorphic temperatures.

\section{Consequences for the tectonic evolution}

The preserved original stratigraphic geometry between the Sesia-Lanzo Zone, the regolith, and the BVS is essential for the interpretation of the tectonic evolution of the region.

The post-Eocene tectonic activity along the Canavese Line, concentrating within the pre-existing mylonitic belt of the tectonic mélange, lets the mutual geometrical relationships between the rocks of the Sesia-Lanzo Zone, the regolith, and the BVS undisturbed. Only locally (Passobreve and Bocchetta di Sessera) is the stratigraphic sequence affected by weak cataclastic faulting with minor offsets.

Field relationships indicate that tilting, and consequent burial, of the rocks of the BVS and the adjacent SesiaLanzo Zone must precede the intrusion of the Valle del Cervo Pluton (31 Ma; Romer et al. 1996). A major argument for the burial of the BVS before the emplacement of the Valle del Cervo Pluton is the distance between the pluton and the rocks of the BVS, which is less than one kilometer in the Valle del Cervo. Accepting an intrusion depth of the pluton of 4-7 km (e.g., Zanoni et al. 2008, 2010 and literature therein), the minimal distance between the pluton and the BVS should be more or less equal to the intrusion depth. Furthermore, in Valle del Cervo (and only there), the rocks of the Sesia-Lanzo Zone (the country rocks of the intrusion) and BVS are crosscut by an anastomosing subvertical network of mineralized veins and breccia pipes, probably related to the hydrothermal activity generated by the intrusion (Bernardelli et al. 2000). Tilting after the intrusion would have two major consequences: (1) 4-7 km of the rocks of the Sesia-Lanzo Zone would have been sheared off between the pluton and BVS; (2) The pluton itself would have been tilted. However, Bernardelli et al. (2000) described in detail the profile between the pluton and the Canavese Line in Valle del Cervo and did not mention any major tectonic feature able to reduce an at least $4 \mathrm{~km}$ thick block of the Sesia-Lanzo Zone between the pluton and the rocks of the BVS. The occurrence of mineralized veins also indicates a certain spatial proximity to the pluton (Bernardelli et al. 2000). Finally, Hrouda and 
Lanza (1989) analysed magnetic foliations and lineations in the Valle del Cervo Pluton. They concluded that the flat foliations and the subvertical lineations are formed during the last stage of the intrusion and have not been strongly affected by any subsequent deformation.

Therefore, the tilting and consequent burial of the BVS and the Sesia-Lanzo Zone must have taken place during the short time between the Late Eocene to Early Oligocene formation of the regolith, on top of the exhumed highpressure metamorphic rocks of the Sesia-Lanzo Zone, and the intrusion of the Valle del Cervo Pluton at $31 \mathrm{Ma}$ (Romer et al. 1996).

\section{Conclusions}

The investigation into the regolith on top of the highpressure metamorphic rocks of the Sesia-Lanzo Zone gives new insights into the evolution of this surface in Oligocene times and the complex alteration history of the regolith after its formation:

- The upper surface of the Sesia-Lanzo Zone can be best described as a regolith developed through weathering in a continental environment.

- Only the saprock, the lowermost part in a regolith profile, is preserved in the analyzed outcrops. The upper parts of the profile like the soil horizon have either never been formed or been eroded.

- Newly developed phases in the regolith, such as chlorite, illite, carbonate, hematite, lepidocrocite, and authigenic quartz, can be related to different alteration processes.

- Except at Bocchetta di Sessera, the regolith is covered by epiclastic rocks of the BVS. They are composed of a polymictic conglomerate containing well-rounded components of volcanic rocks and various amounts of rocks of the Sesia-Lanzo Zone and have been deposited in an alluvial environment.

- The transition between the rocks of the Sesia-Lanzo Zone and the regolith, as well as between the regolith and its volcanic cover, is preserved without any later tectonic overprint.

- Late Eocene to Early Oligocene K-Ar whole rock ages from the overlying rocks of the BVS (Scheuring et al. 1974) provide an earliest Rupelian minimum age of the regolith.

- Illite, chlorite, and carbonate thermometry indicates a re-heating of the whole surface sequence to temperatures up to $250-300^{\circ} \mathrm{C}$.

- Tilting and burial must be closely related.

- Tectonic processes responsible for the tilting and burial of the paleosurface, and its adjacent rocks, must precede the emplacement of the Valle del Cervo Pluton at $31 \mathrm{Ma}$ (Romer et al. 1996).

Acknowledgments This work was supported by a Swiss National Research Foundation grand no. 200020-124331.

\section{References}

Arkai P (1991) Chlorite crystallinity: an empirical approach and correlation with illite cristallinity, coal rank and mineral facies as exemplified by Palaeozoic and Mesozoic rocks of northeast Hungary. J Metamorphic Geol 9:723-734

Babist J, Handy MR, Konrad-Schmolke M, Hammerschmidt K (2006) Precollisional, multistage exhumation of subducted continental crust: the sesia zone, western Alps. Tectonics 25(TC6008)

Beccaluva 1, Bigioggero B, Chiesa S, Colombo A, Fanti G, Gatto G, Gregnanin A, Montrasio A, Piccirillo EM, Tunesi A (1985) Post collisional orogenic dyke magmatism in the Alps. Memorie della Società Geologica Italiana 26:341-360

Berckhemer H (1968) Topographie des "Ivrea-Körpers" abgeleitet aus seismischen und gravimetrischen Daten. Schweiz Miner Petrogr Mitt 48:235-246

Bernardelli P, Castelli D, Rossetti P (2000) Tourmaline-rich orebearing hydrothermal system of lower Valle del Cervo (Western Alps, Italy): field relationships and petrology. Schweiz Miner Petrogr Mitt 80:257-277

Bertolani M (1954) Contributo allo studio petrografico della cosidetta "formazione dioritico-kinzigitica"; Ricerche in Val Sabbiola (Valsesia). Rendiconti della Società Mineralogica Italiana Rendiconti della Società Mineralogica Italiana 10:92-207

Bertolani M (1959) La formazione basica "Ivrea-Verbano" e la sua posizione nel quadro geologico-petrografico della bassa Val Sesia e del Biellese. Periodico di Mineralogia 28:151-209

Bianchi A, Dal Piaz GB (1963) Gli inclusi di "micascisti eclogitici" della Zona Sesia nella formazione porfiritica permiana della Zona del Canavese fra Biella ed Oropa: caratteristiche ed età dei fenomeni metamorfici. Giorn Geol 31:39-76

Bigioggero B, Colombo A, Del Moro A, Gregnanin A, Macera P, Tunesi A (1994) The Oligocene Valle del Cervo Pluton: an example of shoshonitic magmatism in the Western Italien Alps. Mem Soc Geol It 46:409-421

Birkeland PW (1984) Soils and geomorphology. Oxford University Press, New York, p 372

Boulangé B, Ambrosi JP, Nahon D (1997) Laterites and bauxites. In: Paquet H, Clauer N (eds) Soil and sediments: mineralogy and geochemistry. Springer, Berlin, pp 49-65

Bousquet R, Engi M, Gosso G, Oberhänsli R, Berger A, Spalla MI, Zucali M, Goffe B (2004) Transition from the Central to the Western Alps. Mitteilungen der Oesterreichischen Mineralogischen Gesellschaft 149:145-156

Callegari E, Cigolini C, Medeot O, D’Antonio M (2004) Petrogenesis of calc-alkaline and shoshonitic post-collisional oligocene volcanics of the cover series of the Sesia Zone, Western Italien Alps. Geodinamica Acta 17:1-29

Carraro F (1966) Scoperta di una serie carbonifera di coperture degli Gneiss-Sesia. Boll Soc Geol It 85:241-252

Clark I, Fritz P (1997) Environmental isotopes in geology. Lewis Publishers, New York, p 328

Compagnoni R (1977) The Sesia-Lanzo Zone: high pressure-low temperature metamorphism in the Austroalpine continental margin. Rend Soc Ital Miner Petrol 33:281-334

Dal Piaz GV (1999) The Austroalpine-Piemont nappe stack and the puzzle of western Alpine Thetys. Mem Sci Geol 51:155-176 
Frey M (1986) Very low-grade metamorphism of the Alps-an introduction. Schweiz Miner Petrogr Mitt 66:13-27

Friedmann I, O'Neil JR (1977) Compilation of stable isotope fractionation factors of geochemical interest. In: Fleischer M (ed) Data of geochemistry, US Geological Survey Professional Paper 440-KK, 6th edn. USGS, Reston

Giese P (1968) Die Struktur der Erdkruste im Bereich der Ivrea-Zone. Ein Vergleich verschiedener seismischer Interpretationen und der Versuch einer petrographisch-geologischen Deutung. Schweiz Miner Petrogr Mitt 48:261-284

Goffé B, Schwartz S, Lardeaux JM, Bousquet R (2004) Metamorphic structure of the Western and Ligurian Alps. Mitteilungen der Oesterreichischen Mineralogischen Gesellschaft 149:125-144

Handy MR, Babist J, Rosenberg CL, Wagner R, Konrad M (2005) Decoupling and its relation to strain partitioning in continental lithosphere-insight from the periadriatic fault system (European Alps). In: Brun JP, Cobbold PR, Gapais D (eds) Deformation mechanisms, rheology and tectonics: from minerals to the lithosphere. Geol Soc Spec Publ 243

Hey MH (1954) A new review of the chlorites. Mineralog Magaz 30: 277-292

Hrouda F, Lanza R (1989) Magnetic fabric in the Biella and Traversella stocks (Periadriatic Line): implications for the mode of emplacement. Phys Earth Planet Inter 56:337-348

Kent-Corson ML, Ritts BD, Zhuang G, Bovet PM, Graham SA, Chamerberlain CP (2009) Stable isotopic constraints on the tectonic, topographic, and climatic evolution of the northern margin of the Tibetan Plateau. Earth Planet Sci Lett 282:158-166

Konrad-Schmolke M, Babist J, Handy MR, O'Brien PJ (2006) Insight into the physico-chemical properties of a subducted slab from garnet zonation patterns (Sesia Zone, western Alps). J Petrol 47:2123-2148

Kretz R (1983) Symbols for rock-forming minerals. Am Mineralog 68:277-279

Kübler B (1967) La cristallinité de l'illite et les zones tout à fait supérieures du metamorphisme. In: Etages tectoniques, Colloque de Neuchâtel, pp 105-122

Lanza R (1977) Paleomagnetic data from the Andesitic and Lamprophyric Dikes of the Sesia-Lanzo Zone (Western Alps). Schweiz Miner Petrogr Mitt 57:281-290

Lanza R (1979) Paleomagnetic data on the andesitic cover of the Sesia-Lanzo Zone (Western Alps). Geologische Rundschau 68:83-92

Leier A, Quade J, DeCelles P, Kapp P (2009) Stable isotopic results from paleosol carbonate in South Asia. Paleoenvironmental reconstructions and selective alteration. Earth Planet Sci Lett 279:242-254

Malaroda R (1966) Carta Geologica d'Italia, Foglio 43, "Biella", II ed. Serv Geol It, Roma

McNally GH (1992) Engineering geology of duricrusts. In: Branagan DF, Williams KF (eds) Papers of the fifth Edgeworth David day symposium, Sep 1992. The Edgeworth David Society, Sydney. University of Sydney: 89-96

Merrill GP (1897) A treatise on rocks, rock weathering and soils. Macmillan, New York

Pognante U (1991) Petrological constraints on the eclogite- and blueschist-facies metamorphism and $P-T-t$ paths in the western Alps. J Metamorphic Geol 9:5-17
Pognante U, Talarico F, Rastelli N, Ferrati N (1987) High pressure metamorphism in the nappes of the Valle dell'Orco traverse (Western Alps collisional belt). J Metamorphic Geol 5:379-414

Rivalenti G, Garuti G, Rossi A (1975) The origin of the IvreaVerbano basic formation (western Italian Alps); whole rock chemistry. Boll Soc Geol It 94:1149-1186

Romer RL, Schärer U, Steck A (1996) Alpine and pre-Alpine magmatism in the root-zone of the Western Central Alps. Contrib Miner Petrol 123:138-158

Rossetti P, Agangi A, Castelli D, Padoan M, Ruffini R (2007) The Oligocene Biella pluton (Western Alps, Italy): new insights on the magmatic versus hydrothermal activity in the Valsessera roof zone. Per Mineral 76 (Special Issue: In honour of Ezio Callegari on his retirement): $223-240$

Rubatto D, Gebauer D, Compagnoni R (1999) Dating of eclogitefacies zircons: the age of Alpine metamorphism in the SesiaLanzo Zone (Western Alps) Earth Planet Sci Lett 167:141-158

Ruxton BP, Berry L (1957) Weathering of granite and associated erosional features in Hong Kong. Geol Soc Am Bull 68:1263-1291

Scheuring B, Ahrent H, Hunziker JC, Zingg A (1974) Paleobotanical and geochronological evidence for the alpine age of the metamorphism in the Sesia-Zone. Sonderdruck aus der Geologischen Rundschau 63:305-326

Schmid SM, Aebli HR, Heller F, Zingg A (1989) The role of the Periadriatic Line in the tectonic evolution of the Alps. In: Coward MP, Dietrich D, Park RG (eds) Alpine tectonics. Geol Soc Spec Publ 45:153-171

Sheppard SMF (1986) Characterization and isotopic variations in natural waters. In: Valley JW, Taylor HP, O'Neil JR (eds) Stable isotopes in high temperature geological processes. Miner Soc Am Chelsea: 165-183

Taylor G, Eggleton RA (2001) Regolith geology and geomorphology. John Wiley \& Sons Ltd, Chichester, p 375

Vecchia O (1968) La zone Cuneo-Ivrea-Locarno, élément fondamental des Alpes. Géophysique et Géologie. Schweiz Miner Petrogr Mitt 48:215-226

Vuichard JP, Ballèvre M (1988) Garnet-chloritoid equilibria in eclogitic pelitic rocks from the Sesia Zone (Western Alps): their bearing on phase relations in high pressure metapelites. J Metamorphic Geol 6:135-157

Zanoni D, Spalla MI, Gosso G, Zucali M (2008) Plutoni tardocollisionali nella crosta profonda esumata della Zona Sesia Lanzo: implicazioni per la geodinamica delle Alpi Occidentali Interne. Rend Online SGI Note Brevi 1:199-202

Zanoni D, Spalla MI, Gosso G (2010) Structure and PT estimates across late-collisional plutons: constraints on the exhumation of western Alpine continental HP units. Inter Geol Rev 52:1244-1267

Zingg A, Hunziker JC (1990) The age of movements along the insubric line west of Locarno (northern Italy and southern Switzerland). Eclogae geologicae Helvetiae 83(3):629-644

Zingg A, Hunziker J, Frey M, Ahrendt H (1976) Age and degree of metamorphism of the Canavese zone of the sedimentary cover of the Sesia zone. Schweiz Miner Petrogr Mitt 56:361-375 